\title{
Picraux Leads MRS in 1993
}

Tom Picraux is the 1993 President of the Materials Research Society, a position he assumes automatically from his elected office of First Vice President in 1992. While Picraux sees himself as only one player in a large cast of contributors to MRS, he looks forward to guiding the society as it celebrates its 20th anniversary. "I can think of no other professional society that could be as exciting to lead," he says.

Picraux would like to see MRS contribute more broadly to the materials community. He plans to accomplish this by expanding technical representation within MRS, by enhancing MRS contributions to national and international science policy, and by promoting the recognition of materials research as a significant and fundamental branch of science.

Picraux believes MRS can maintain its quality and vitality, while continuing to grow as a society, simply by building on the successful formula it currently employs. "We have to keep our technically strong people highly involved," he says. "It is through the strength and creativity of dedicated volunteers and the flexibility of our technical program that we are able to produce meetings that reflect the materials trends of the times and the interests of our members."

"Another factor contributing to the vitality of MRS," says Picraux, "is the way in which our volunteers interact with our staff." It is important, he says, that MRS volunteers determine the technical content and the direction of the society, while the professional staff provides the high-level organization required for putting the society's plans into action in a timely and professional way. This balance makes it possible for MRS to respond quickly to significant materials developments, while keeping society activities driven by the active members.

Picraux first became active in MRS in the late $1970 \mathrm{~s}$, during the early days of laser annealing. He chaired several symposia in the 1980s, but the challenge of chairing the 1987 Fall Meeting won his allegiance to MRS. Afterward, he served as Program Committee Chair and was a Councillor of the Society from 1988 until 1990. In 1991 he was elected Second Vice President, and the following year, First Vice President.

A native of Missouri, Tom Picraux grew up on a farm, amidst strawberries, hay, and wheat. After high school he attended the University of Missouri, where he re-

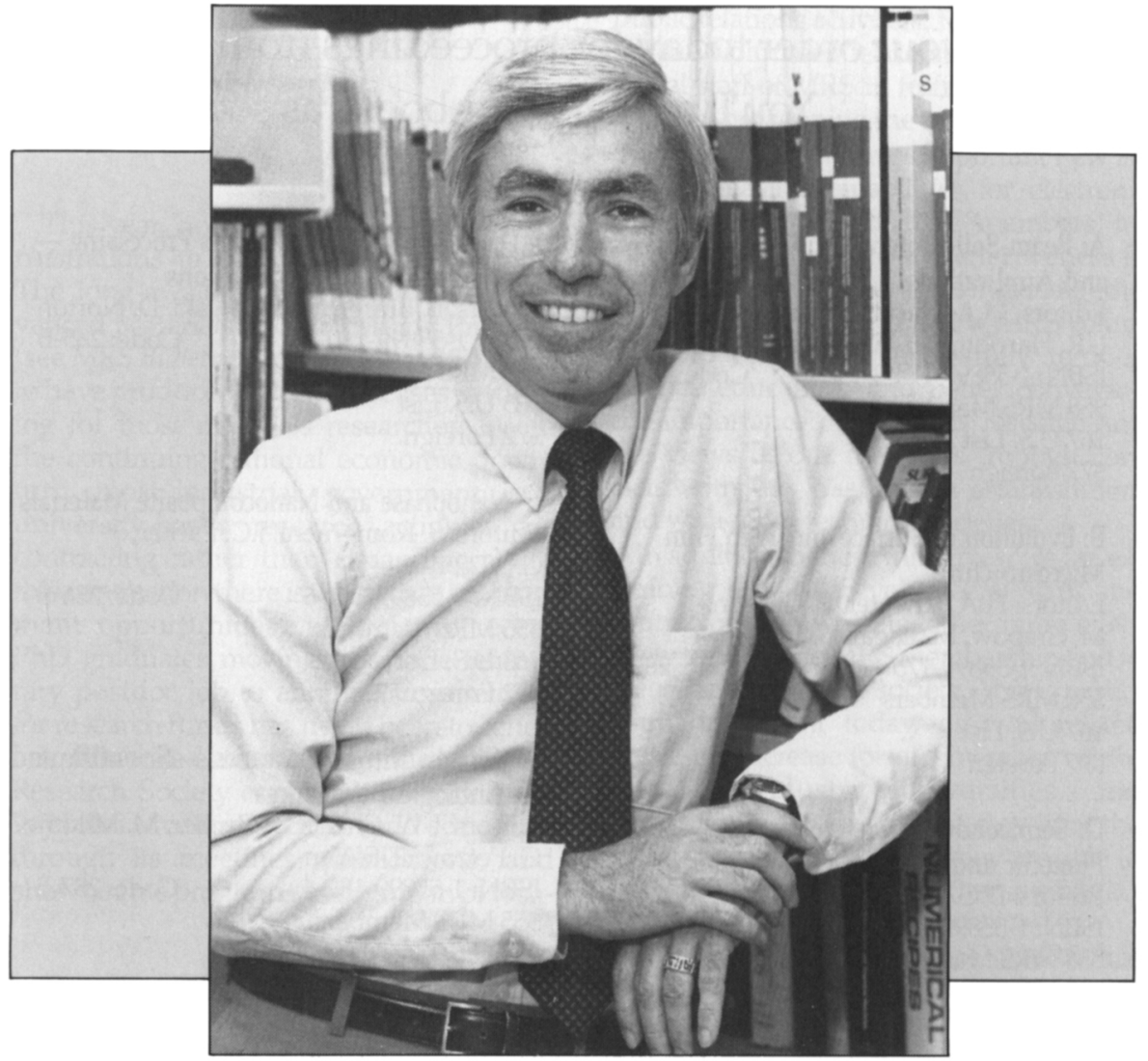

ceived a BS degree in electrical engineering. Picraux then went on to Cambridge University as a Fulbright Fellow in physics, and later received his $\mathrm{PhD}$ degree in engineering science and physics from the California Institute of Technology.

Picraux is manager of the Semiconductor Physics Research Department at Sandia National Laboratories. He joined Sandia in 1969 as a member of the technical staff in ion-solid interactions research. Since 1972 he has managed various solid-state science activities at Sandia, including ion beam science, surface and interface science, defect physics, microsensor research, and semiconductor physics. Picraux is recognized for his development of ion channeling and its application to materials research. In 1990 he received the Department of Energy's E.O. Lawrence Award for materials research, based on this work.

Picraux has published more than 200 papers, and has served on such National Research Council studies as the 1986 Materials Science Briefing on Advanced Processing of
Electronic Materials in the United States and Japan, and the 1988 Study on Photonics. He was a founding editor and, until 1992, coeditor of the Joumal of Nuclear Instruments and Methods, Section B, and currently serves on the editorial boards of several journals.

During the 1970s and 1980s, Picraux served on international conference committees on ion beam analysis and materials modification. He is a fellow of APS and was chair of the APS Materials Physics Division during 1990-91. He has also served on advisory boards at Argonne, Lawrence Livermore, and Lawrence Berkeley National Laboratories, and at the University of Texas at Austin.

Picraux enjoys traveling, and has been a visiting scientist at Aarhus University, $\mathrm{Ca}$ tania University, AT\&T Bell Labs, Chalk River Labs, and Hughes Research Labs. This year he anticipates that his travels will take him to Strasbourg for the E-MRS meeting and to Tokyo for ICAM-93, the IUMRSsponsored meeting on advanced materials. 


\section{M[RTS 1992 FALL MEETING \\ MATERIALS

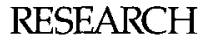 \\ SOCIETY

\section{Place your order today for proceedings from the 1992 MRS Fall Meeting in Boston. You'll receive your books as soon as they are published.}

A: Beam-Solid Interactions - Fundamentals and Applications

Editors: M.A. Nastasi, N. Herbots, L.R. Harriott, R.S. Averback ISBN: 1-55899-174-3

Code: $279-B$

$\$ 58$ MRS Members

\$67 U.S. List

$\$ 77$ Foreign

\section{B: Evolution of Surface and Thin Film}

Microstructure

Editors: H.A. Atwater, E. Chason,

M. Grabow, M. Lagally

ISBN: 1-55899-175-1

Code: $280-B$

\$58 MRS Members

$\$ 67$ U.S. List

$\$ 77$ Foreign

D: Semiconductor Heterostructures for

Photonic and Electronic Applications

Editors: D.C. Houghton, C.W. Tu, R.T. Tung

ISBN: 1-55899-176-X

Code: 281-B

$\$ 58$ MRS Members

\$67 U.S. List

$\$ 77$ Foreign

E: Chemical Perspectives of Microelectronic Materials III

Editors: C.R. Abernathy, C.W. Bates,

D.A. Bohling, W.S. Hobson

ISBN: $1-55899-177-8$

Code: $282-B$

$\$ 58$ MRS Members

\$67 U.S. List

$\$ 77$ Foreign

F: Microcrystalline Semiconductors -

Materials Science \& Devices

Editors: Y. Aoyagi, L.T. Canham

P.M. Fauchet, I. Shimizu, C.C. Tsai

ISBN: 1-55899-178-6

Code: 283-B

$\$ 60$ MRS Members

\$69 U.S. List

\$79 Foreign

G: Amorphous Insulating Thin Films

Editors: J. Kanicki, R.A.B. Devine,

W.L. Warren, M. Matsumura

ISBN: 1-55899-179-4

Code: $284-B$

$\$ 60$ MRS Members

$\$ 69$ U.S. List

$\$ 79$ Foreign

Standard shipping charges of $\$ 3.00$ per book will be added to each order. Contact MRS for special shipping.
I: Laser Ablation in Materials Processing -

Fundamentals and Applications

Editors: B. Braren, J. Dubowski, D. Norton

ISBN: 1-55899-180-8

Code: 285-B

$\$ 55$ MRS Members

$\$ 63$ U.S. List

$\$ 72$ Foreign

J: Nanophase and Nanocomposite Materials Editors: S. Komarneni, J.C. Parker,

G.J. Thomas

ISBN: 1-55899-181-6 Code: 286-B

\$55 MRS Members

$\$ 63$ U.S. List

$\$ 72$ Foreign

K: Silicon Nitride Ceramics - Scientific and Technological Advances

Editors: I-W. Chen, P.F. Becher, M. Mitomo, G. Petzow, T-S. Yen

ISBN: 1-55899-182-4

Code: $287-B$

$\$ 55$ MRS Members

\$63 U.S. List

$\$ 72$ Foreign

L: High-Temperature Ordered Intermetallic Alloys V

Editors: I. Baker, J.D. Whittenberger

R. Darolia, M.H. Yoo

ISBN: 1-55899-183-2

$\$ 60$ MRS Members

Code: $288-B$

$\$ 69$ U.S. List

$\$ 79$ Foreign

M: Flow and Microstructure of Dense

Suspensions

Editors: L.J. Struble, C.F. Zukoski, G. Maitland

ISBN: 1-55899-184-0

Code: 289-B

$\$ 60$ MRS Members

$\$ 69$ U.S. List

$\$ 79$ Foreign

$\mathrm{N}$ : Dynamics in Small Confining Systems

Editors: J.M. Drake, D.D. Awschalom,

J. Klafter, R. Kopelman

ISBN: 1-55899-185-9

Code: 290-B

$\$ 60$ MRS Members

$\$ 69$ U.S. List

$\$ 79$ Foreign
O: Materials Theory and Modelling

Editors: P.D. Bristowe, J. Broughton,

J.M. Newsam

ISBN: 1-55899-186-7

Code: 291-B

$\$ 60$ MRS Members

\$69 U.S. List

$\$ 79$ Foreign

S: Biomolecular Materials

Editors: S.T. Case, J.H. Waite, C. Viney

ISBN: 1-55899-187-5

Code: 292-B

$\$ 60$ MRS Members

\$69 U.S. List

$\$ 79$ Foreign

U: Solid State Ionics III

Editors: G-A. Nazri, J-M. Tarascon,

$M$. Armand

ISBN: 1-55899-188-3

Code: $293-B$

$\$ 60$ MRS Members

\$69 U.S. List

$\$ 79$ Foreign

V: Scientific Basis for Nuclear Waste

Management XVI

Editors: C.G. Interrante, R.T. Pabalan

ISBN: 1-55899-189-1

$\$ 55$ MRS Members

\$63 U.S. List

$\$ 72$ Foreign

W: Atomic-Scale Imaging of Surfaces and Interfaces

Editors: D.K. Biegelson, D.S.Y. Tong,

D.J. Smith

ISBN: 1-55899-190-5

Code: $295-B$

$\$ 60$ MRS Members

$\$ 69$ U.S. List

$\$ 79$ Foreign

Y: Structure and Properties of Energetic Materials

Editors: R.W. Armstrong, J.J. Gilman

ISBN: 1-55899-191-3

$\$ 60$ MRS Members

Code: $296-B$

\$69 U.S. List

$\$ 79$ Foreign

\section{ORDER FROM:}

MATERIALS RESEARCH SOCIETY

9800 McKnight Road, Pittsburgh, PA 15237, (412) 367-3012; FAX (412) 367-4373.

In Europe, Africa, or the Middle East, contact: Clarke Associates - Europe Ltd.

13a Small Street, Bristol BS11DE, England; Phone: 0272 268864; FAX 0272226437 